Goldschmidt 2021 Abstract

https://doi.org/10.7185/gold2021.4396

\title{
Outgassing of Metals from Active Volcanoes
}

MARIE EDMONDS, EMILY MASON AND OLIVIA HOGG

University of Cambridge

Presenting Author: me201@cam.ac.uk

Erupting basaltic volcanoes outgas large quantities of metals into the atmosphere, in some cases comparable to the industrial output of entire countries. What can we learn from volcanic outgassing about the magmatic processing of chalcophile metals in the crust?

We discuss a range of case studies globally that show that basaltic volcanoes in arc settings outgas a distinct assemblage of elements from those in ocean island settings. Arc gases and aerosols are enriched in elements such as $\mathrm{Tl}, \mathrm{Cd}, \mathrm{Bi}, \mathrm{Pb}$ and $\mathrm{Cu}$. Some of these metals speciate with chloride; the higher chloride contents of arc magmas over those in ocean island settings enhances their partitioning into an exsolved saline fluid phase (e.g. $\mathrm{Cu}, \mathrm{Pb}$ ). Other elements are inherently enriched in arc melts through transfer from the slab during devolatilisation (e.g. Bi, Tl, $\mathrm{Cd}$ ) and hence also become enriched in the hydrous exsolved fluids in arc magmas.

A complex interplay between silicate melt, exsolved aqueous fluids and sulfide phases exists in magmas degassing at low pressures in the crust. Sulfides sequester chalcophile metals when silicate melts reach saturation with respect to sulfide. Upon magma degassing and the formation of a hydrous exsolved volatile phase, sulfides break down, releasing their chalcophiles back into the silicate melt-hydrous exsolved volatile phase system. The process of sulfide breakdown may contribute particular elements to the outgassing volcanic plume.

We compare the fluid-melt partition coefficients and $[\mathrm{X}] /[$ sulfur $]$ and $[\mathrm{X}] /[$ chlorine $]$ ratios (where $\mathrm{X}$ is a chalcophile metal) we estimate for metals and metalloids in the volcanic gas plume in basaltic systems with those derived from direct analysis in silicate melt and vapour-brine phases in fluid inclusions trapped in porphyry minerals. The volcanic plume is depleted in metals relative to sulfur compared to the fluids that are trapped in porphyry minerals and relative to bulk porphyry deposits themselves. We discuss the link between outgassing low density vapour and the fluids generated by fluid-melt partitioning from evolved silicate melts at depth; and the possible segregation of brine phases in the subsurface at some actively outgassing volcanoes. 